\title{
Demographic and dental profile of patients met in the Dental Center for Patients with Special Needs of the Brazilian Association of Dentistry - Rio de Janeiro
}

\author{
Bruna Lavinas Sayed Picciani, ${ }^{1,2}$ Bruna Michalski dos Santos, ${ }^{1,2,3}$ Geraldo Oliveira Silva-Júnior, ${ }^{1,3,4}$ Thays Teixeira de Souza, ${ }^{1,3}$ Marcelo Daniel Brito Faria, \\ Luciana Freitas Bastos ${ }^{3,5}$ \\ ${ }^{1}$ Dental Center for Patients with Special Needs, Brazilian Association of Dentistry, Rio de Janeiro, RJ, Brazil \\ ${ }^{2}$ Department of Stomatology, Fluminense Federal University, Nova Friburgo, RJ, Brazil \\ ${ }^{3}$ Center of Dental Radiology and Care to Patients with Special Needs, Piquet Carneiro Polyclinic, Rio de Janeiro State University, Rio de Janeiro, RJ, Brazil \\ ${ }^{4}$ Department of Diagnosis and Therapeutics, School of Dentistry, Rio de Janeiro State University, RJ, Brazil \\ ${ }^{5}$ Department of Preventive and Community Dentistry, School of Dentistry, Rio de Janeiro State University, RJ, Brazil \\ - Conflicts of interest: none declared.
}

\section{Abstract}

Objective: to evaluate the demographic and dental profile of patients with special needs met in a Reference Center in the state of Rio de Janeiro, showing their main needs and the possibility of outpatient care. Material and Methods: the sample consisted of 410 patients, from whom demographic and clinical data were obtained. All the studied variables were entered in a database for descriptive statistical analysis. Results: two hundred and twenty-seven (55\%) patients were male, $70 \%$ were white, and their average age was 34 years old. Inconclusive diagnosis, followed by autism spectrum disorder and intellectual disabilities, were the most found diagnoses. Most patients (78\%) was from the metropolitan region. Regarding complaints and dental procedures, the main complaint was prevention (28\%), and 2,902 procedures were performed. Concerning oral hygiene habits, $264(64 \%)$ patients did not floss and $215(52 \%)$ underwent toothbrushing three times a day. Only $57(14 \%)$ cases required the use of sedative methods to carry out the dental treatment. Conclusion: there is a great demand for preventive and restorative treatments for patients with special needs, highlighting the need for daily strengthening practices of oral health promotion. In addition, we can see that most treatments performed were in the outpatient level, showing that the use of appropriate approach is essential for dental management, thus demystifying the care of these patients. Keywords: Patients with special needs; Oral health; Dental treatment; Patients with disabilities; Special dentistry.

\section{Introduction}

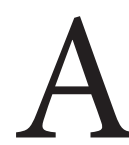
ccording to Gullikson (1973), a special patient is any person, adult or child, who physically, intellectually, socially, or emotionally diverges from what is considered normal regarding growth and development patterns. Thus, these patients cannot receive regular and standardized education, requiring special education and supplementary instruction in appropriate services for the rest of their life. ${ }^{1}$

The World Health Organization (WHO) estimates that the prevalence of disabilities in the world is of one every ten people, and says that, of this total, more than two thirds does not receive any type of oral health care. ${ }^{2,3}$ Most of these individuals lives in underdeveloped or developing countries, with only $2 \%$ receiving adequate care focused on their needs. In Brazil, according to sources of IBGE (2002), 24.5 million people have special needs, i.e., 14.5\% of the Brazilian population have some type of disability. ${ }^{4}$

According to the National Policy of People with Disabilities (Política Nacional da Pessoa com Deficiência) - tool of the Brazilian Ministry of Health that guides the several sectors of health care to meet people with disabilities -, the comprehensive health care of these patients include oral and dental care, accompanied by hospital procedures and others, in specific cases. ${ }^{5}$

Dental problems, especially periodontal disease and tooth decay, are frequent in these patients. This fact can be explained by the inability of patients and their guardians in maintaining a proper oral hygiene; the social, economic, and cultural condition of many patients with special needs (PSN); motor limitations; the insufficient number of specialized professionals to meet them; lack of attention of public agencies; lack of motivation and inadequate training of parents and caregivers regarding oral hygiene; and lack of preventive programs. ${ }^{6-9}$

Unfortunately, nowadays, this large group of patients are still unattended and discriminated, being excluded from society and showing poor oral health conditions. For some dentists, meeting patients with special needs may present some difficulties, generating an idea that this service is infeasible in the outpatient level. Therefore, it is greatly important to know the profile and promote the social inclusion of these patients, providing an egalitarian dental treatment. ${ }^{5}$

Thus, this study aimed to evaluate the demographic and dental profile of patients with special needs met in a Reference Center in the state of Rio de Janeiro, showing their main needs and the possibility of outpatient care. 


\section{Material and Methods}

This was a descriptive, cross-sectional, and retrospective study, with data collection from 410 medical records of patients met at the Dental Center for Patients with Special Needs of the Brazilian Association of Dentistry of Rio de Janeiro, from 2010 to 2015. The following variables were collected for further analysis: sex, skin color, age, origin, medical diagnosis, dental complaint, frequency of toothbrushing, flossing, dental procedure carried out, and need of sedative methods to carry out the dental treatment. The data were grouped into a data collection program (Microsoft Excel 2010), and the descriptive variables were arranged by descriptive statistics (frequency, mean, standard deviation, standard error). The study was approved by the Research Ethics Committee of the Rio de Janeiro State University, under CAAE: 24279314100005259/2014.

\section{Results}

The sample consisted of 410 patients, and most were male $(227-55 \%)$ and had white skin color $(288-70 \%)$. Age ranged between 2 and 90 years old, with an average age of 34 years $(\mathrm{SD}=22$ years) and median of 29 years (Table 1 ). Most patients were in the 11-30 age group (164-40\%) and were from the metropolitan region (85\%) (Figure 1). The most found medical diagnoses were: 50 (12\%) inconclusive, 48 (11\%) autistic spectrum disorders, 40 (10\%) Down syndrome, 40 (10\%) intellectual disabilities, and 37 (9\%) cerebral palsy (Figure 2). Regarding complaints, the main cause for seeking care was prevention, reported by 117 (28\%) patients (Figure 3). Concerning oral hygiene habits, 264 (64\%) patients did not floss and 215 (52\%) underwent or already performed toothbrushing three times a day (Figure 4). Regarding dental treatment, 2,902 procedures were carried out, with an average of seven procedures per patient, and the most frequent were: 949 (32\%) restorations, 495 (17\%) topical applications of fluoride, 443 (15\%) prophylaxis, and 426 (14\%) tooth extractions (Table 2). Only 57 (14\%) cases required the use of sedative methods to carry out the dental treatment; 21 (37\%) patients were subjected to the dental treatment under general anesthesia and 20 (35\%) underwent oral sedation (Figure 5).

Table 1. Distribution of the sample according to the demographic profile

\begin{tabular}{c|c|c|c}
\hline \multirow{2}{*}{ Variable } & \multirow{2}{*}{ Category } & \multicolumn{2}{|c}{ Sample } \\
\cline { 3 - 4 } & & $\mathbf{N}=410$ & $\%$ (100) \\
\hline \multirow{2}{*}{ Sex } & Female & 183 & 45 \\
& Male & 227 & 55 \\
\hline \multirow{3}{*}{ Skin color } & White & 288 & 70 \\
& Mixed-race & 86 & 21 \\
& Black & 36 & 9 \\
\hline \multirow{4}{*}{ Age (years) } & Min-Max & \multicolumn{2}{|c}{$2-90$} \\
& Mean (SD) & \multicolumn{2}{|c}{$34(22)$} \\
& Median & \multicolumn{2}{|c}{29} \\
& Mode & \multicolumn{2}{|c}{21} \\
\hline
\end{tabular}

\section{Rio de Janeiro State - Mesoregions}

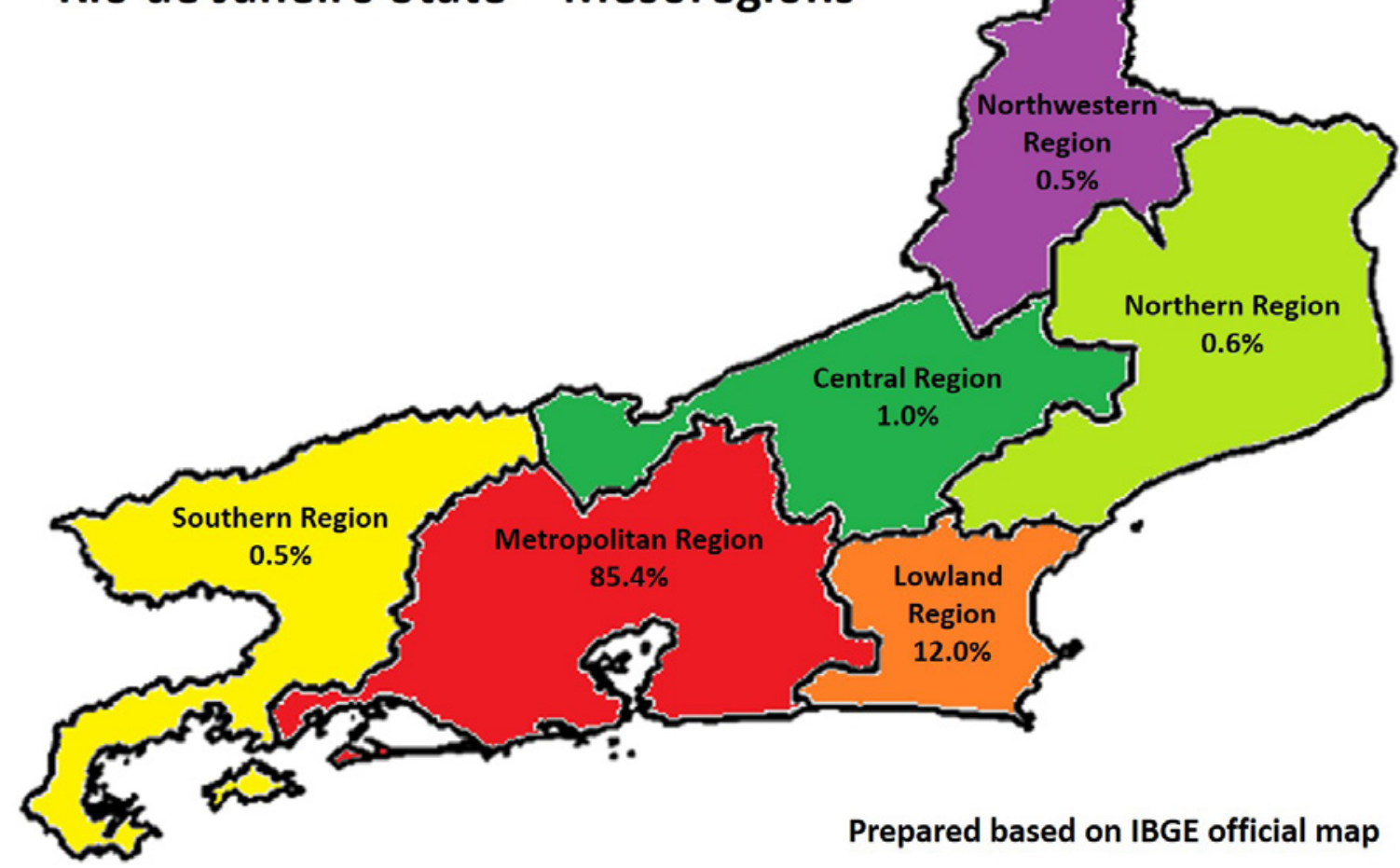

Figure 1. Distribution of the sample according to the mesoregions of the state of Rio de Janeiro 


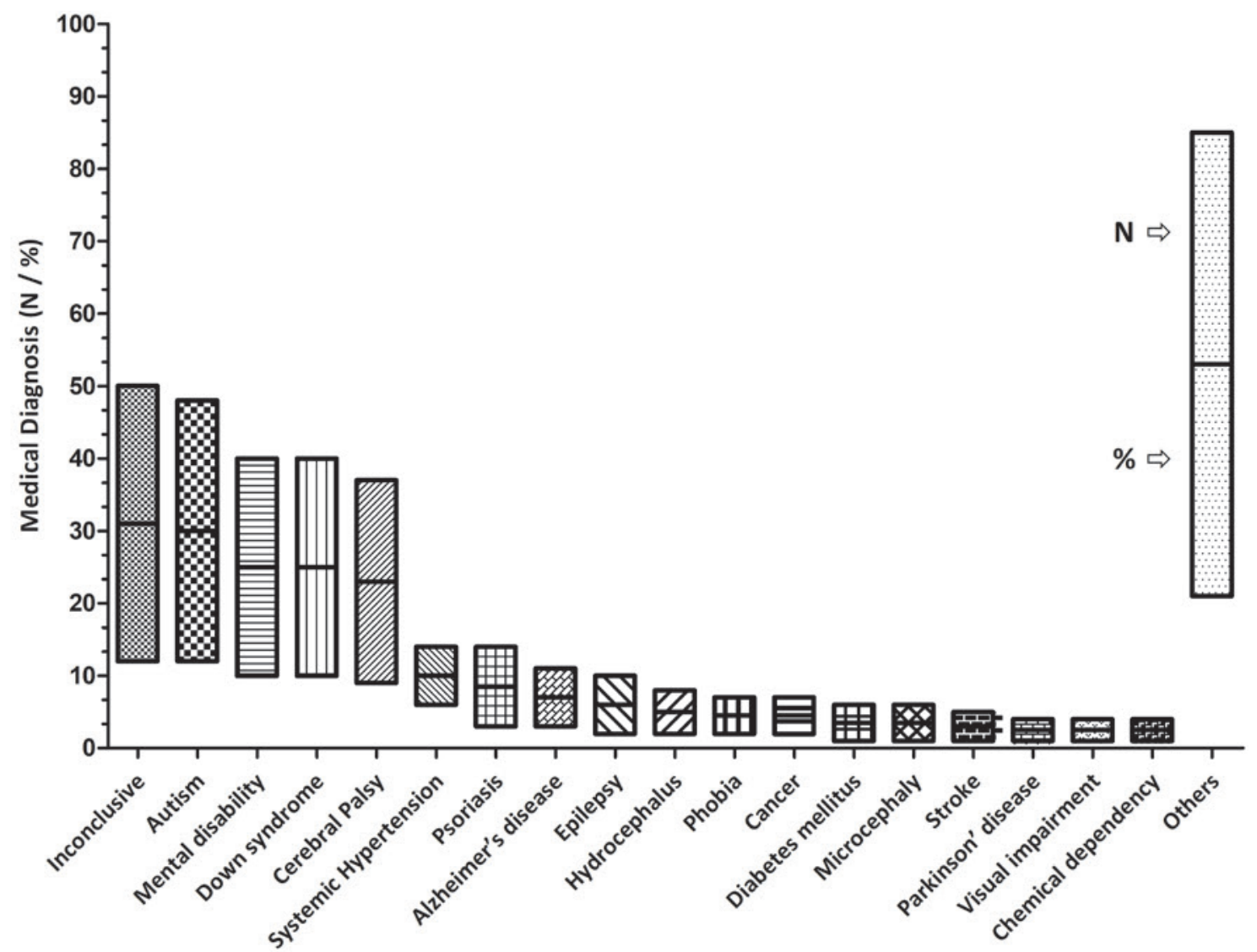

Figure 2. Distribution of the sample according to the medical diagnoses. $(\mathrm{N}=$ Number of patients, $\%=$ Percentage)

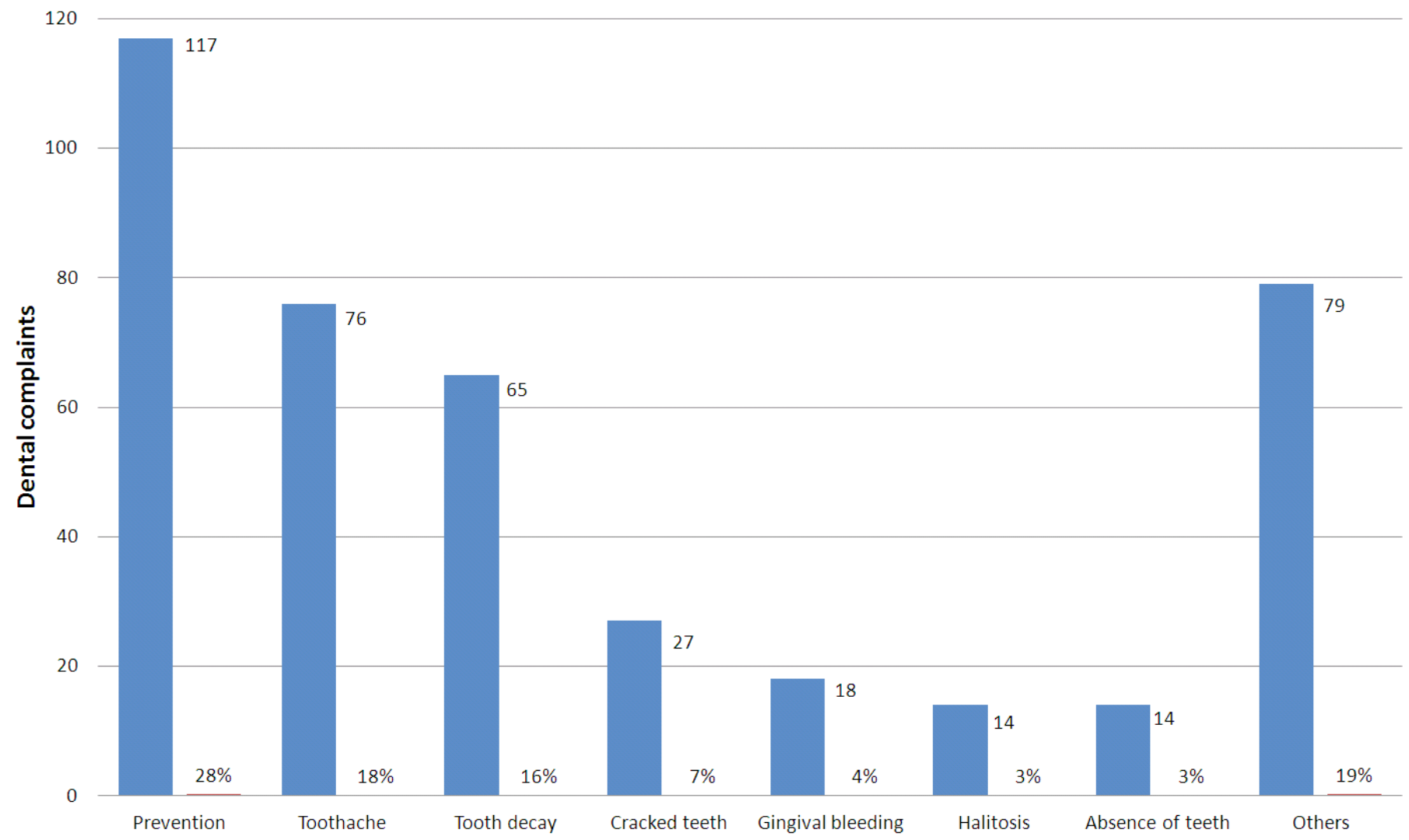

Figure 3. Distribution of the sample according to the main dental complaints 


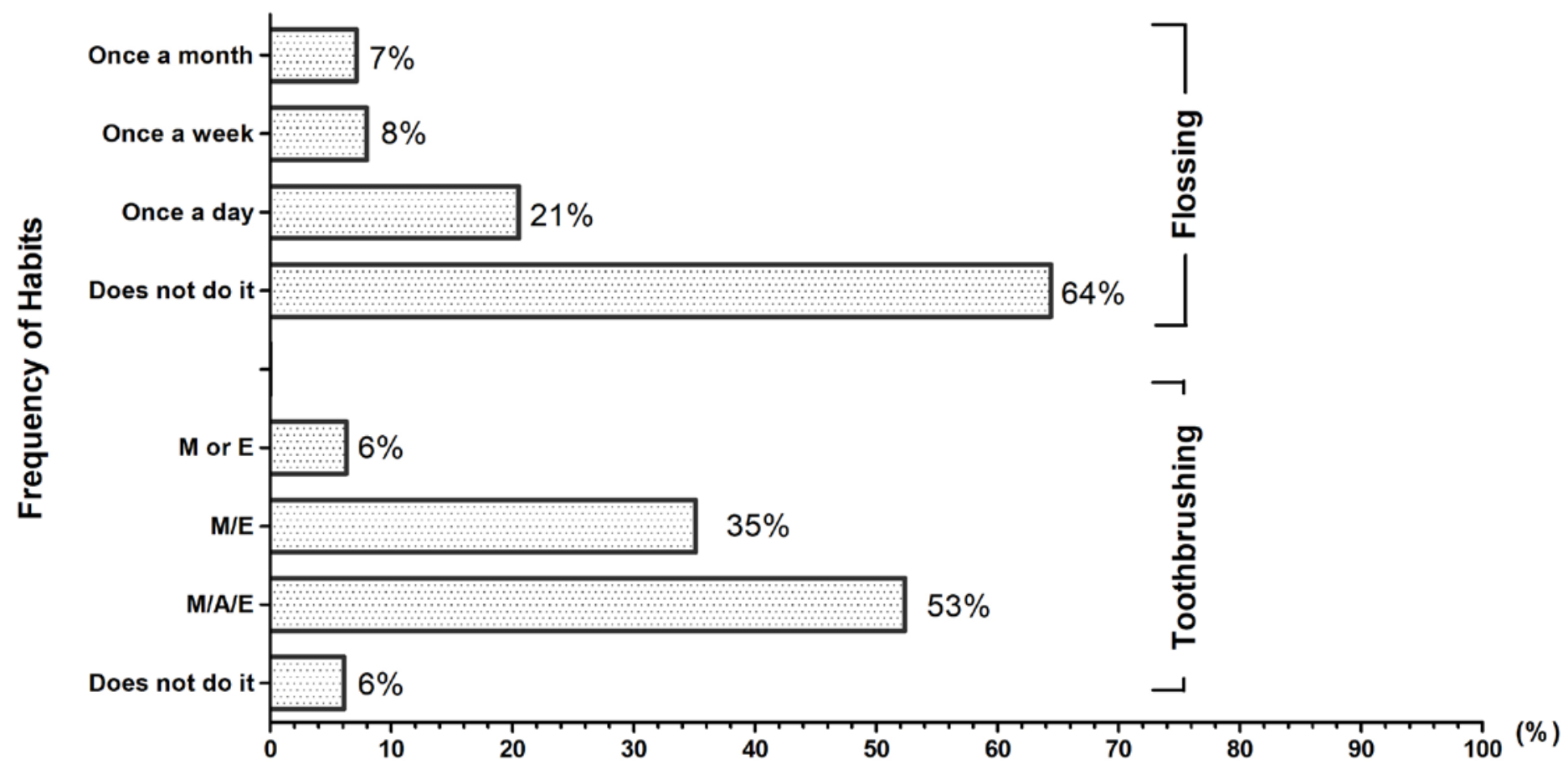

Figure 4. Frequency of oral hygiene habits according to tooth brushing and flossing ( $M$ or $E=$ Morning or Evening, $M / E=M o r n i n g / E v e n i n g, ~ M / A / E$ $=$ Morning/Afternoon/Evening)

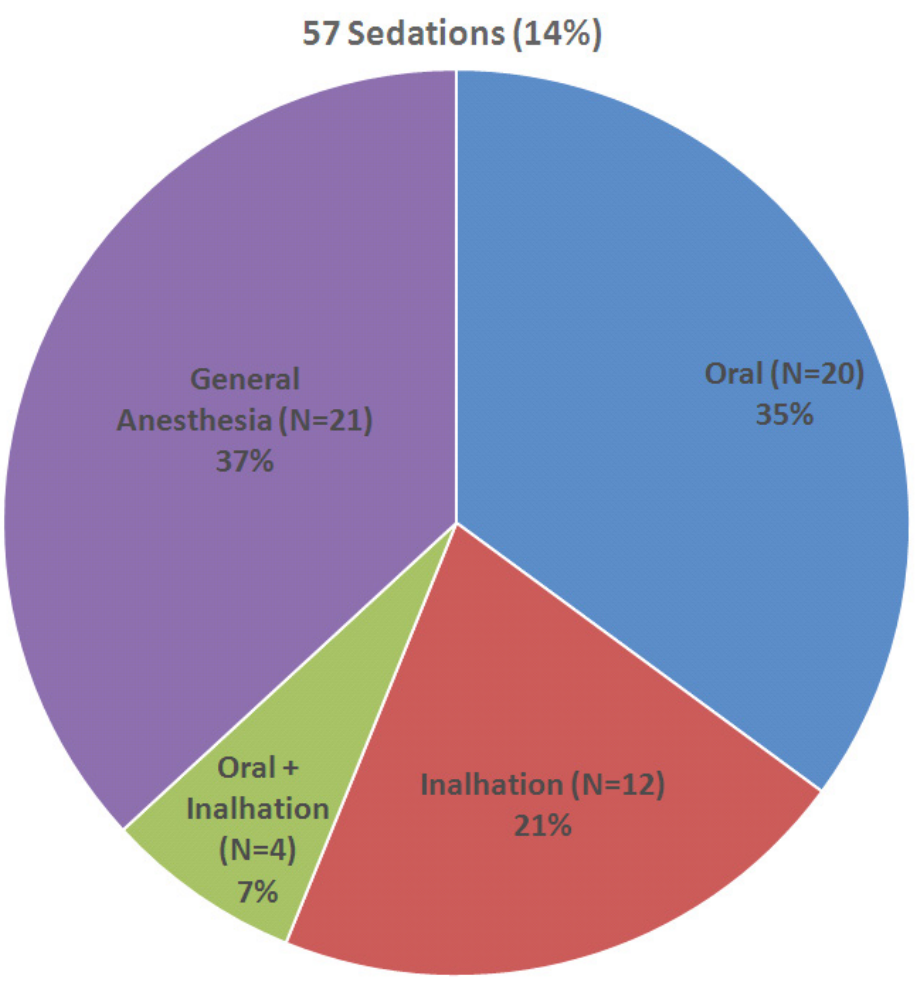

Figure 5. Distribution of the sample according to sedative methods employed
Table 2. Distribution of the sample according to the main dental procedures carried out

\begin{tabular}{l|c|c}
\hline \multirow{2}{*}{\multicolumn{1}{c}{ Procedures }} & \multicolumn{2}{c}{ Sample } \\
\cline { 2 - 3 } & $\mathbf{N =}$ & $\%$ (100) \\
\hline Restoration & 949 & 32 \\
\hline Topical Applications of Fluoride & 495 & 17 \\
\hline Prophylaxis & 443 & 15 \\
\hline Tooth Extractions & 426 & 14 \\
\hline Supragingival Scaling & 309 & 10 \\
\hline Periapical Radiography & 241 & 8 \\
\hline Endodontic Treatment & 40 & 1.2 \\
\hline Removable Denture & 29 & 1 \\
\hline Full and Partial Crown & 19 & 0.6 \\
\hline Gingivectomy & 4 & 0.1 \\
\hline Orthodontic Treatment & 4 & 0.1 \\
\hline
\end{tabular}




\section{Discussion}

The dental care to patients with special needs requires specific care, and knowing the clinical and demographic profile of these individuals is essential. Information such as age group, age to seek care, origin, diagnosis, main complaint, and oral hygiene habits are essential so that the professionals involved can prepare an appropriate treatment plan, establishing protocols of humanized and personalized care that show and reinforce the importance of dentistry in the multidisciplinary treatment of patients with special needs.

This study has shown that the sociodemographic profile presented no difference regarding sex, with a slightly increased frequency of males compared to females (55\% and $45 \%$, respectively). These data are similar to Silva et al., ${ }^{10}$ who identified $52 \%$ of males and $48 \%$ of females. According to the data of the 2010 Census, conducted by the Brazilian Institute of Geography and Statistics (IBGE), until 2010, 26\% of the female population (25 million) had some disability, against $21 \%$ of the male population (19 million) ${ }^{11}$ Regarding skin color, our data showed prevalence of white skin color, with $70 \%$ of all individuals. These results may be associated to a restriction of access to specialized dental care by mixed-race and black populations, which still greatly represent the low-income population in the state of Rio de Janeiro and in Brazil. According to IBGE (2010) data, racial groups differ concerning epidemiological, demographic, socioeconomic characteristics and access to services. ${ }^{11}$ Rohr and Barcellos report that the socioeconomic condition is a significant factor for the use of oral health services, in which individuals from the most favored economic classes seek more for dental services. ${ }^{12}$

Regarding age, we identified a range from 2 to 90 years old, in which younger patients often presented congenital and behavioral anomalies. According to Silva et al. ${ }^{10}$ and Acerbi et al., ${ }^{13}$ these data may represent the lower life expectancy of these individuals compared to the population, reinforcing the importance of providing a specialized care in the early years of life. Individuals with chronic systemic diseases were older, corroborating the literature that shows higher prevalence of these conditions in the age group above 40 years old. ${ }^{3-5}$

It is important to observe the origin of $22 \%$ of the patients, who were living outside the capital, but sought care at the Center for lack of specialized services, which is against the basic principles of universality and equity of the Brazilian Unified Health System (SUS). These data corroborate several other studies that also identified the profile of patients with special needs met in specialized centers, showing the inequity of access to oral health care of the population who does not live in the metropolis. ${ }^{10,14-17}$ This information reinforce the importance of establishing partnerships with universities outside the metropolitan region of Rio de Janeiro to promote greater inclusion of these patients, in addition to encourage education and motivation programs of oral hygiene to be held by undergraduate students in dentistry, which makes their academic training more complete and safe within an inclusive context.

Concerning the diagnoses identified among these patients, this medical information was obtained from 410 individuals, and the highest percentage was of inconclusive diagnoses, which are mostly associated with bad congenital formations. According to Camelier et al., ${ }^{18}$ despite the molecular origins of congenital malformations are increasingly known, an average of 50 to $60 \%$ of cases occur because of unknown causes. Then, the diagnosis of autistic spectrum disorder was obtained, with $11 \%$, followed by Down syndrome, with $10 \%$. According to Rutter ${ }^{19}$, the prevalence of autism in the world's population varies from 4 to $13 / 10,000$, occupying the third place among child development disorders, being ahead of Down syndrome.

Regarding the need to seek care, most (28\%) guardians were seeking preventive measures, reporting great concern with oral problems, since they might cause further damage in the physical and mental integrity of the patient. However, an advanced age was found for patients seeking their first care (average of 34 years old). These data can be justified by an exhaustive routine of medical consultations, which may lead to actions of neglect and forgetfulness concerning oral health care. In addition to this, there is still a significant lack of knowledge of the importance of dental monitoring and education for providing a best quality of life to special patients since their first years of life. ${ }^{20}$ Casamassimo et al. ${ }^{21}$ conducted a study in which they reinforce the difficulty of dentists in meeting patients with limitations. Their research showed that only one every four professionals could work with this type of patient during their undergraduate studies, not presenting difficulty in the care of these children. The reduced number of services and professionals specialized for this care decreases the supply of service.

Concerning oral hygiene habits, most guardians and/or caregivers reported performing toothbrushing three times a day, but not always effectively, given the difficulty in handling. We observed that flossing is rarely performed, since it is not a common practice in everyday life. This situation is aggravated by the lack of training programs for caregivers, financial cost, unfamiliarity of parents regarding the pos- 
sibilities of training, and prioritization of the treatment of other systemic problems. According to Flório et al., ${ }^{22}$ when PSN are not able to perform oral hygiene care by themselves, the caregiver becomes responsible for it. However, they often feel little motivated or have no knowledge on how to perform a satisfactory oral hygiene, besides reporting difficulties in performing it. The difficulties, according to the caregivers, are associated with handling these individuals, since most present motor limitations, aggressive behavior, and lack of interest and cooperation. ${ }^{22}$

Factors such as poor oral hygiene, unprivileged socioeconomic condition, mouth breathing, occlusion anomalies, cariogenic diet, and use of medicines are common in patients with special needs. ${ }^{23,24}$ This study found that, among the procedures performed, restorative and preventive treatments were prevalent. In general, individuals with special needs have a higher prevalence of tooth decay. ${ }^{25}$ This meets with the large number of restorative procedures identified in this study. However, there is a significant number of patients in monitoring and prevention programs, showing that it is possible to change the paradigm of PSN with missing and decayed teeth.

We also found a small percentage of procedures performed in the areas of Endodontics, Prosthodontics, and Orthodontics, showing the feasibility to perform a dentistry that requires more collaboration and has an aesthetic purpose in patients with special needs. Dougall \& Fiske ${ }^{26}$ state that, since the life expectancy of patients with special needs is increasing, the importance of keeping teeth in a stable, healthy, and functional occlusion has become a major focus for improving their quality of life. Thus, there is a tendency to promote more restorative and endodontic treatments rather than tooth extractions. However, it should be noted that such procedures must have a precise indication and a proper collaboration of oral hygiene, by instructions and routine consultations, to ensure the ultimate success of these therapies.

The patient must be introduced to the dental environment in the first year of life, so that the mother receive guidance on the oral hygiene of the child and required preventive measures may be carried out, using psychological conditioning, mainly by talk-show-do techniques, in which the stimuli are gradually presented. ${ }^{27}$ However, some patients do not respond to this approach because they present different degrees of mental impairment that affect their ability to cooperate. In these cases, the alternatives to carry out the dental treatment are preoperative sedation with medication, sedation with nitrous oxide/oxygen, and, in the last case, general anesthesia. ${ }^{28,29}$
Our study showed that, of the 410 patients, only 57 (14\%) required the use of sedative methods, showing that outpatient care to special patients is possible if different methods of adaptation to the environment and to dental care are employed, always with persistence and boldness. Schardosim et al. ${ }^{30}$ mention that the essential tools to carry out outpatient care to PSN are welcoming, desensitization of patients - regardless of their ability to collaborate -, and bonding with the family, making these the major principles that allow the dentist to approach and gain the confidence of the patient.

Of this small number, 21 had their treatment carried out in operating room under general anesthesia. It is worth noting that this is a precise indication, since the degree of cooperation of the patient and the complexity of the procedure must be carefully examined. ${ }^{31}$

As alternative sedatives methods, conscious sedation was employed with benzodiazepines administered orally and/or inhalation sedation with nitrous oxide and oxygen, which, used safely and effectively, essentially aim to reduce the anxiety and fear of the patient, allowing outpatient care. ${ }^{29}$ These data show that these procedures are a solution, favoring the reduction of dental care in the hospital environment. However, it is important to mention that the in-depth knowledge of these techniques, their risks, and benefits is essential, as well as the monitoring of the vital signs of the patient. ${ }^{32,33}$

\section{Conclusion}

The average profile of patients with special needs is characterized by white male patients, with an average age of 34 years old, from the metropolitan region, with inconclusive diagnoses, autism spectrum disorder, and Down syndrome. In addition to this, a great concern for prevention of oral diseases was observed, despite the late search for dental care and lack of flossing and toothbrushing. Regarding dental treatments, restorative and preventive procedures prevail, with rare use of sedative methods. Thus, by using an appropriate approach, it is possible to perform outpatient dental care to these individuals, which is fundamental to reestablish and maintain their quality of life.

\section{Acknowledgments}

This study was supported by the Brazilian Association of Dentistry - Rio de Janeiro and by FAPERJ (Fundação Carlos Chagas Filho de Amparo à Pesquisa do Estado do Rio de Janeiro, www.faperj.br), with the process E-26/111.806/2013). 


\section{References}

1. Gullikson JS. Oral findings in children with Down's syndrome. ASDC J Dent Child. 1973;40(4):293-7.

2. Yue J, Lu H, Lan S, Liu J, Stein MN, Haffty BG, et al. Identification of the DNA repair defects in a case of Dubowitz syndrome. PLoS One. 2013;8(1):e54389.

3. Schliehe F, Ewert T. The International Classification of Functioning, Disability and Health (ICF) - update of the problem based inventory. Rehabilitation (Stuttg). 2013;52(1):40-50

4. __________asil. Ministério da Saúde. Secretaria de Atenção à Saúde. Política Nacional de Saúde da Pessoa Portadora de Deficiência / Ministério da Saúde, Secretaria de Atenção à Saúde - Brasília: Editora do Ministério da Saúde, 2008. 72 p.

5. Holder M, Waldman HB, Hood H. Preparing health professionals to provide care to individuals with disabilities. Internat J Oral Sci. 2009;1(2):54-9.

6. Sabbagh-Haddad A, Magalhães MHG. Introdução. In: Sabbagh-Haddad A. Odontologia para pacientes com necessidades especiais. São Paulo: Editora Santos; 2007.

7. Bönecker M, Cleaton-Jones P. Trends in dental caries in Latin American and Caribbean 5-6 and 11-13-year-old children: a systematic review. Community Dent Oral Epidemiol. 2003;31(8):152-7.

8. Berman DS, Slack GL. Dental caries in English school children: a longitudinal study. Br Dent J. 1972;133(6):529-38.

9. Guimarães LOC. Contribuição para o estudo da bilateralidade da cárie dentária em dentes permanentes. Rev Fac Odontol São Paulo. 1971;9(1):311-8.

10. Silva ZCM, Pagnonceli SD, Weber JBB, Fritscher AMG. Avaliação do perfil dos pacientes com necessidades especiais da clínica de odontopediatria da faculdade de odontologia da PUCRS. Revista Odonto Ciência - Fac. Odonto/PUCRS. 2005;50(20):313-8.

11. IBGE - Instituto Brasileiro de Geografia e estatística. PAS - Pesquisa Anual de Serviços, 2010. [online] Available from: http://www.ibge.gov.br/home/estatistica/ecnomia/comercioeservico/pas/pas2010.

12. Rohr RIT, Barcellos LA. As principais barreiras de acesso a serviços odontológicos. UFES Rev Odontol. 2008;10(3):37-41.

13. Acerbi AG, Freitas C, Magalhães MH. Prevalence of numeric anomalies in the permanent dentition of patients with Down syndrome. Spec Care Dentist. 2001;21(2):75-8.

14. Kuhn-Dall Magro A, Dall'Magro E, Kuhn GF. Perfil clínico dos pacientes especiais tratados sob anestesia geral no Hospital São Vicente de Paulo de Passo Fundo entre os anos 2005 e 2010. RFO. Passo Fundo. 2010;15(3):253-6.

15. Alencar TO, Smith CA, Passos LT, Pinheiro HC, Menezes SAF. Perfil dos pacientes especiais de uma clínica de odontopediatria. RBPS. Fortaleza. 2011;24(2):133-41. 16. Previtali EF, Ferreira MCD, Santos MTBR. Perfil dos pacientes com necessidades especiais atendidos em uma instituição de ensino superior. Pes Bras Odontoped Clin Integr. 2012;12(1):77-82.

17. Domingues NB, Ayres KCM, Mariusso MR, Zuanon ACC, Giro EMA. Caracterização dos pacientes e procedimentos executados no serviço de atendimento a pacientes com necessidades especiais da Faculdade de Odontologia de Araraquara - UNESP. Rev Odontol UNESP. 2015;44(6):345-50.

18. Camelier V, Ramos R, Pereira VF, Reis T, Amorim G, Cerqueira E, et al. Estudo do campo na Bahia e em Salvador: impacto na notificação das malformações congênitas. Gaz Méd Bahia. 2007;77(supl.1):55-9.

19. Rutter M. Incidence of autism spectrum disorders: changes over time and their meaning. Acta Paediatr. 2005;94(3):2-15.

20. Mugayar LF. Pacientes portadores de necessidades especiais: manual de odontologia e saúde oral. 1a edição. São Paulo: Pancast; 2000.

21. Casamassimo PS, Seale NS, Ruehs K. General dentists' perceptions of educational and treatment issues affecting access to care for children with special health care needs. J Dent Educ. 2004;68(1):23-8.

22. Flório FM, Basting RT, Salvatto MV, Migliato KL. Saúde bucal em indivíduos portadores de múltiplas deficiências. RGO. 2007;55(3):251-6.

23. Vellapally S, Gardens SJ, Al Kheraif AA, Khrisna M, Babu S, Hashem M, et al. The prevalence of malocclusion and its association with dental caries among 12-18 years old disabled adolescents. BMC Oral Health. 2014;14(1):123:1-7.

24. Sinha N, Singh B, Chhabra KG, Patil S. Comparison of oral health status between children with cerebral palsy and normal children in India: a case-control study. J Indian Soc Periodontol. 2015;19(1):78-82.

25. Oredugba F.A.; Akindayomi Y. Oral health status and treatment needs of children and young adults attending a day centre for individuals with special health care needs. BMC Oral Health. 2008;8(30):1-8.

26. Dougall A, Fiske J. Access to special care dentistry, part.1. Access British Dent J. 2008;204:605-15.

27. Corrêa MSNP. Odontopediatria na primeira infância. In: Corrêa MSNP, Maia MES, SanglardPeixoto LF. Abordagem do comportamento para o atendimento odontopediátrico. $2^{\text {a }}$ ed. São Paulo: Santos; 2005. p.187-202.

28.Juarez-López L, Saavedra-García M, Ramírez González G. Estudio comparativo entre dos esquemas de sedación em pacientes odontopediátricos. Bol Méd Hosp Infant Mex.1998;55(7):443-51.

29. Picciani BLS, Humelino MG, Michalski BS, Costa G, Silva-Júnior GO, Fidalgo FB, et al. Nitrous oxide/oxygen inhalation sedation: an effective option for odontophobic patients. Rev. bras. odontol. 2014;71(1):72-5.

30. Schardosim LS, Costa JRS, Azevedo MS. Abordagem odontológica de pacientes com necessidades especiais em um centro de referência no Sul do Brasil. Revista de Odontologia da Universidade Federal de Pelotas. 1-11, 2015.

31. Lim MAWT, Borromeo GL. The use of general anesthesia to facilitate dental treatment in adult patients with special needs. J Dent Anesth Pain Med. 2017;17(2):91-103 32. Cavalcante LB, Sanabe ME, Marega T, Gonçalves JR, Braga FC. Conscious sedation: a backup resource for providing dental care to uncooperative children. Arq Odontol, Belo Horizonte. 2011;47(1):45-50.

33. American Academy of Pediatric Dentistry. Definition of special health care needs. Pediatr Dent. 2016;38(special issue):16.

\section{Mini Curriculum and Author's Contribution}

1. Bruna Lavinas Sayed Picciani - DDS and PhD. Contribution: Performed the data collection, manuscript writing, manuscript review.

2. Bruna Michalski dos Santos - DDS and MSc. Contribution: Performed the data collection, manuscript writing, manuscript review.

3. Geraldo Oliveira Silva-Júnior - DDS and PhD. Contribution: Performed the data collection, manuscript writing, manuscript review.

4. Thays Teixeira de Souza - DDS and MSc. Contribution: Performed the data collection and wrote the manuscript.

5. Marcelo Daniel Brito Faria - DDS and PhD. Contribution: Performed the data collection, manuscript writing, manuscript review, work supervisor.

6. Luciana Freitas Bastos - DDS and PhD. Contribution: Performed the data collection, manuscript writing, manuscript review, work supervisor.

Submitted: 12/20/2017 / Accepted for publication: 02/15/2018

\section{Corresponding Author}

Bruna Lavinas Sayed Picciani

E-mail: brunapicciani@gmail.com 